\title{
Demand articulation in emerging technologies: Intermediary user organisations as co-producers?
}

\author{
Wouter P.C. Boon*, Ellen H.M. Moors, Stefan Kuhlmann, Ruud E.H.M. Smits \\ Innovation Studies Group, Copernicus Institute for Sustainable Development and Innovation, Faculty of Geo-sciences, Utrecht University, Heidelberglaan 2, \\ 3584 CS Utrecht, The Netherlands
}

\section{A R T I C L E I N F O}

\section{Article history:}

Received 16 April 2009

Received in revised form

15 September 2010

Accepted 15 September 2010

Available online 15 October 2010

\section{Keywords:}

User involvement

Intermediary organisations

Demand articulation

Emerging technology

\begin{abstract}
A B S T R A C T
User involvement is assumed to be beneficial to innovation processes. Intermediary user organisations contribute to articulating societal demands for innovations. However, the learning processes inside these organisations are still not understood well. Therefore, this paper empirically investigates intermediaries using an event history approach. It yields characteristic learning mechanisms, e.g. concerning the management of expectations or actively building a case. If intermediaries overcome challenges regarding positioning, representation and the level of proactivity, they can play a precarious role in demand articulation in the context of new technologies.
\end{abstract}

(c) 2010 Elsevier B.V. All rights reserved.

\section{Introduction}

In recent decades intermediary organisations have gained in importance because of an increase in different sorts of actors involved in the innovation process and the related need for translating and transferring knowledge (Van Lente et al., 2003). Examples include strategic alliances, spin-offs, joint ventures, innovation centres, incubators, and science parks. Empirical research shows that the number and variety of intermediaries is growing as well (Braun, 1993; Van der Meulen et al., 2005). The initial focus of studies into intermediary organisations was on the science-policy boundary, e.g. research councils (Bal et al., 2004), but soon broadened with the inclusion of small and medium-sized enterprises, knowledge intensive business services (Bessant and Rush, 1995; Den Hertog, 2000; Kaufmann and Tödtling, 2001), and the emphasis on the increasing role of users (Davenport et al., 2003; Moors et al., 2008). In science and technology studies there is ample literature on intermediary organisations, mainly as part of health social movements (Hess et al., 2008) and representative advocacy organisations (Epstein, 2008).

\footnotetext{
* Corresponding author. Present address: Department of Innovation Studies, Utrecht University, The Netherlands. Tel.: +31 20 5986193; fax: +31 204447027.

E-mail addresses: w.boon@geo.uu.nl, wouter.boon@falw.vu.nl (W.P.C. Boon), e.moors@geo.uu.nl (E.H.M. Moors), s.kuhlmann@utwente.nl (S. Kuhlmann), r.smits@geo.uu.nl (R.E.H.M. Smits).
}

Several scholars especially emphasise the importance of including users in innovation contexts and processes in the early phases of technological development, when the technology and related aspects, such as regulation, societal acceptance, are still malleable, open-ended and uncertain (Rothwell et al., 1974; Von Hippel, 1978, 1988; Oudshoorn and Pinch, 2003; Smits and Boon, 2008). The creative potential and experiential knowledge of users might benefit forming new technologies and putting demands on the agenda of, for example businesses and governments. This is also in line with increasing attention for demand-oriented innovation policy (Edler and Georghiou, 2007; Edler, 2010). Moreover, taking into account the preferences of users might facilitate the adoption and implementation of new innovations, as well as broaden, enrich and democratise debates about controversial topics around these technologies.

Users and producers of innovations come from different backgrounds and their interactions can be facilitated by what we call intermediary user organisations. During the fruition of new technologies, intermediary user organisations develop ideas and needs about (aspects of) these new technologies. The organisations engage in learning processes about their demands regarding the emerging technology through demand articulation processes (Boon et al., 2008). Demand articulation concerns learning inside intermediary organisations and is extensively studied in the literature on (constructive) technology assessment. However, the technology assessment literature focuses on the process of generating and acquiring knowledge needed as an input in demand articulation processes (Smits et al., 1995; Schot and Rip, 1996). Moreover, 
learning has extensively been studied in the context of organisations (Cohen and Sproull, 1995), but focuses primarily on individual behaviour and adaptation by organisations as a whole (Meeus et al., 2001).

In this light, the objective of this article is to obtain insight into the role intermediary user organisations play in the context of new technologies, and how they attempt to influence these technologies. More in particular, the emphasis is on how learning about different aspects of new technologies inside these intermediaries takes place. This article adds to the user involvement studies in general but also builds on literature about: (1) intermediary organisations (e.g. Howells, 2006; Klerkx and Leeuwis, 2009), especially those representing users, (2) studies on the dynamics of development and learning (e.g. Van de Ven et al., 1999; Robinson et al., 2007) and (3) studies on technology assessment, more particular on the role of users in participatory TA processes (Smits et al., 1995; Schot and Rip, 1996; Hennen, 1999). In this way, recommendations can be made to orient innovation policy and management more towards the demands of a heterogeneous group of users by regarding intermediary user organisations as co-producers of new technologies. This is achieved by answering the following research questions: which learning mechanisms are discerned inside intermediary user organisations articulating their demands? Are the developed conceptual model and methodology useful to study processes of demand articulation in a particular sector, i.e. the health care sector in the Netherlands, and to what extent can this methodology also be used to analyse user involvement in the development of emerging technologies in a different context? And, which are the implications of the results for policy and for intermediary organisations?

To answer these questions, learning processes are systematically studied in three intermediary user organisations in the health care sector in the Netherlands. Sections 2 and 3 explicate the theory and methodology behind demand articulation in intermediary user organisations. Section 4 gives the results of the analyses of the three cases, whereas Section 5 presents the conclusions, discussion and recommendations.

\section{Intermediary user organisations and demand articulation}

\subsection{Intermediary user organisations}

In recent years, the involvement of intermediary organisations in improving interactions in relation to research and development has attracted more attention. Howells (2006) provides a literature overview of intermediary innovation organisations, which he defines as an "organisation or body that act[s] an agent or broker in any aspect of the innovation process between two or more parties", and states that a theoretical focus on and an univocal definition of intermediaries are lacking.

This definition remains rather indefinite because intermediary organisations can have different roles and functions at once (Galli and Teubal, 1997). Improving interaction can take many forms, including: delegate, steer, inform, coordinate, support, legitimate, aggregate, be a platform, be a broker, translate, and advise (Fernandez and Gould, 1994).

Besides the variety of definitions, categorisations and functions, intermediary organisations have also been studied from several theoretical perspectives, such as social network theory (Burt, 1992), principal-agent theory (Van der Meulen and Rip, 1998; Braun and Guston, 2003), economic theories on market brokerage (Khurana, 2002), and innovation systems literature (Lundvall, 1992; Edquist, 1997).

The facilitation of interactions between users and other actors by intermediary user organisations is also treated in science, technology and innovation studies (Oudshoorn and Pinch, 2003; Epstein,
2008; Hess et al., 2008). This literature underlines the capacity of these user groups to contribute to research processes in several ways. For example:

- They can function as 'network assemblages' that "help weave together networks of patients, funding resources, clinicians and potential researchers" (Hess, 2004).

- They form obligatory passage points (Latour, 1987) in controlling and facilitating boundary conditions and resources of the research and innovation process (Merkx, 2008), such as access to patients for the recruitment of clinical trials. This has ultimately repercussions for the adoption of new technologies (Boon, 2008).

- They contribute to technological developments (Hess, 2005) by expressing creative ideas and by conveying users' experiential knowledge (Von Hippel, 1978; Epstein, 1995; Rabeharisoa, 2003; Smits and Boon, 2008).

- They can be engaged in deliberative processes and debates that enhance the democratic participation in science and technology on behalf of users (Hennen, 1999; Fischer, 2000).

Literature on intermediary user groups regards these organisations as hybrid and boundary-crossing because by definition they bridge and interact with different disciplines, actors, interests, value systems, fields of activity and institutions. These organisations and their members also incorporate distinct epistemic backgrounds as well as underlying normative assumptions. This has also implications for the practices of representation and participation (Epstein, 2008): do the user groups really represent what their members want (Parthasarathy, 2003)? Special attention is needed for the way in which user representatives balance the interests of users, at the same time adhering to scientific knowledge and practices. User groups that focus on the latter are in the process of "expertification" (Epstein, 1995). Another issue connected to the hybrid character of user groups is the degree of independence: how do they gain access to debates about new innovations without running the risk of incorporation by other actors?

Intermediary user organisations are frequently involved in emerging scientific and technological developments. As several aspects of science and technology development become more clear over time (Kodoma, 1995; Rip, 1995), also visions, expectations, needs, ideas and ethical concerns about these developments may change and/or become more articulated. In early development phases of technologies, potential users might have certain still ill-defined 'latent' needs (Orihata and Watanabe, 2000). Users articulate their ideas about the new science or technology during this demand articulation process, i.e. a consciousness-raising process in which users further develop and form their needs, ideas and visions. This article focuses on demand articulation as a learning process that takes place inside organisations, which will be further explained in the next section.

Summing up, several authors have investigated intermediary user organisations in the context of innovation processes. These studies underline that these organisations contribute to and sometimes even create new innovations.

\subsection{Demand articulation as learning processes inside intermediaries}

One of the major publications about learning inside organisations is the work done by Argyris and Schön (1978) in which they describe learning taking the shape of two interconnected learning loops: first-order (single loop) versus second-order (double loop) learning. The first-order loop "connects detected outcomes of action to organisational strategies and assumptions which are modified so as to keep organisational performance within the range set by organisational norms. The norms themselves [...] 


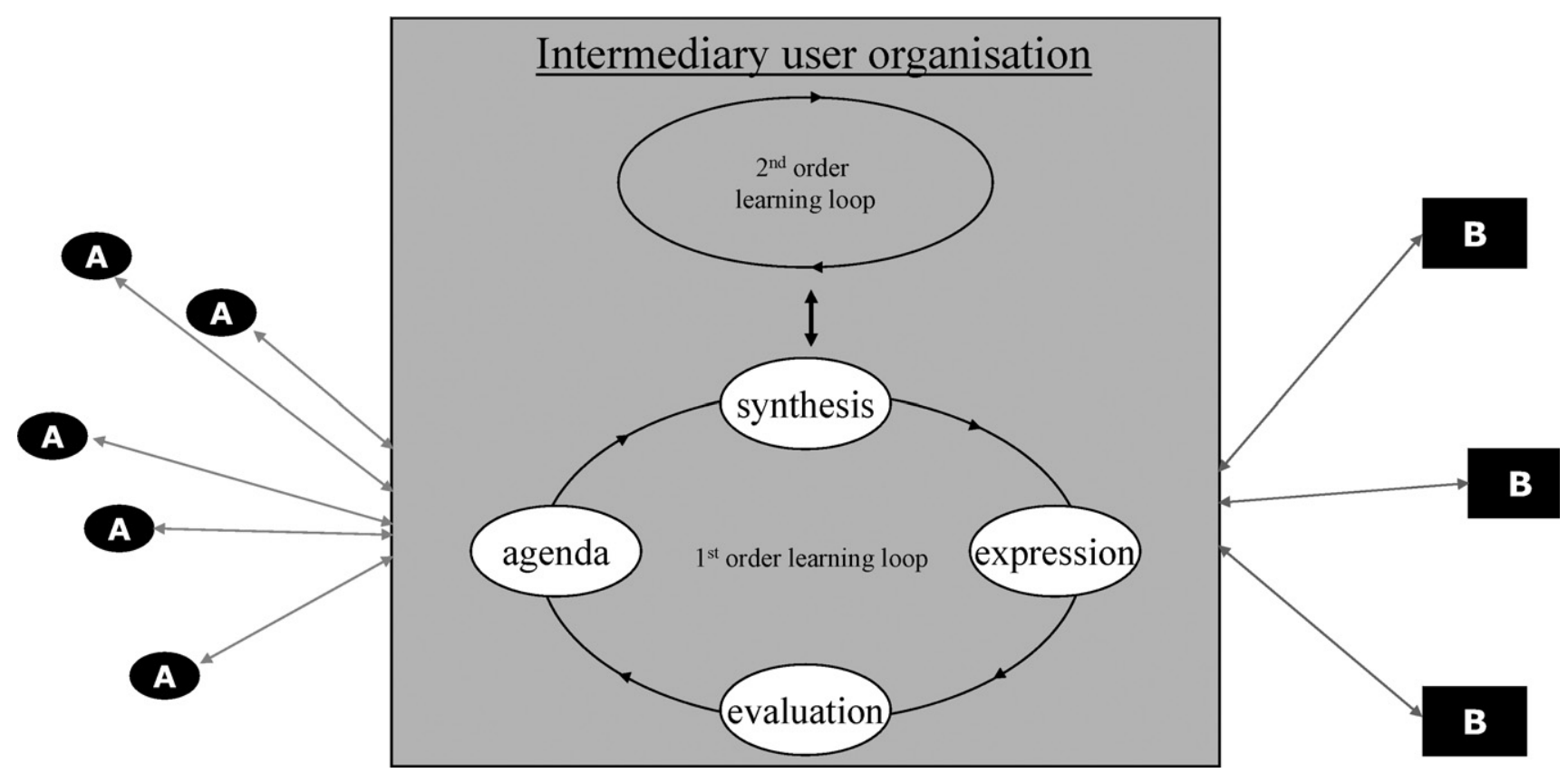

Fig. 1. Conceptual model of demand articulation processes within an intermediary user organisation.

remain unchanged" (Argyris and Schön, 1978). Second-order learning concerns "those sorts of inquiry which resolve incompatible organisational norms by setting new priorities and weightings of norms, or by restructuring the norms themselves together with associated strategies and assumptions" (Argyris and Schön, 1978). Their work was followed in other disciplines, such as policy analysis (Grin and Van de Graaf, 1996a,b) and technology (assessment) studies (Callon, 1986; Bijker et al., 1987; Smits et al., 1995). Another example concerns Van de Ven et al. (1999) who proposed a trialand-error learning process model that is primarily intended to conceptualise processes in innovation project teams within an organisation. There is a constant feedback loop of actions and outcomes, in which shifting goals and outcome criteria also play a role.

In this paper, the first-order learning loop within an intermediary user organisation is conceptualised as a succession of events that include (1) the setting of the organisation's agenda under influence of external and internal actors, (2) the synthesis, (3) expression of demands, and (4) the evaluation of the formation of demands. Different intermediary user organisations run through these loops in different ways, also depending on the characteristics of the issues that are at stake. These differently characterised, situationand issue-dependent learning loops are called demand articulation mechanisms. We focus on these mechanisms in order to achieve the main object of this article, to inform future-oriented governance of emerging technologies by improved understanding of how intermediary user organisations organise demand articulation.

Second-order learning occurs when organisations reflect on their own and other organisation's strategies, objectives and norms. Therefore, second-order learning is about the development of the organisations' underlying assumptions, objectives, and norms. This shapes the organisation's underlying assumptions, which are under constant influence of how other actors perceive the underlying assumptions of the organisation.

One of the hypotheses of this paper is that first-order learning (agenda - synthesis - expression - evaluation) and second-order learning are interconnected (see Fig. 1).

The two learning loops in the conceptual model are studied in the context of three intermediary user organisations in the Dutch health care sector.

\section{Methodology of measuring demand articulation in intermediaries}

As demand articulation and learning are dynamic concepts, a process approach was chosen that focuses on the time ordering of events studied over time. The process approach utilised here is the event history analysis based on Van de Ven and colleagues (1990, 1999; Poole, 2004). In the process approach a unit of analysis is called a central subject. This is the "individual entit[y] [...] around which the narrative is woven" (Van de Ven and Engleman, 2004). The intermediary user organisations are regarded as the central subjects. So-called events happening inside/in relation to these intermediary user organisations constitute the units of measurement. Processes were regarded as sequences of events that together form a narrative that describes how things change over time (Mohr, 1982). The events were categorised into typologies in order to describe processes on a higher level of abstraction, by which different (narratives of) central subjects could be compared. This higher level of abstraction was balanced with the accuracy of interpretation of the typology.

The event history analysis was tailored to studying demand articulation processes in intermediaries and according to the following steps:

1. Quick scan to select event themes: using introductory interviews with the intermediary's representatives, as well as reading (annual) reports of the organisation led to discerning interesting topics or event themes related to emerging technologies. These event themes served as mini-cases within these organisations.

2. Collecting raw data from inside intermediaries: data were obtained from the organisation's archives, using sources such as minutes of (board and committee) meetings, letters, reports and evaluations. Other information sources included more open-access data, such as the organisation's public website. In addition, we conducted interviews with several representatives of these intermediaries ranging from chairmen and managing directors to researchers and secretaries. These interviews were primarily meant to clarify archival information, provided the easiest inroads to the data, and uncovered the underlying assumptions behind the demands that were found. The latter was done by 
bringing an important demand statement issued by the organisation to the attention of the interview respondent. Subsequently 'why-questions' were asked about these statements, in that way descending to the level of the assumptions underlying the statements. Furthermore, for some cases observation methods were also applied, being present during (invitational) conferences and meetings organised by the intermediaries.

3. Collecting raw data from actors who interacted with the intermediaries: this mainly involved obtaining data using open-access material, such as reports and minutes from parliament, reports available through websites, and annual reports. Moreover, interviews were conducted with persons outside the intermediary, who had frequently contacted the organisation during the event sequence, to clarify underlying assumptions, using a schematic overview of the narrative as a mnemonic device and a way to structure these interviews.

4. Enter raw data into a database: see Box 1 for more details on the number of incidents, sources and interview respondents.

5. Identifying events from incidents: raw data incidents were translated into events through coding. A coding scheme was employed based on an operationalisation of the theoretical concepts presented in the previous sections (see Table 1). During coding, validity and interrater reliability were taken into account.

6. Analysis conceptual model: to analyse demand articulation processes inside intermediaries, first-order learning was measured by looking at the growth in demand statements, convergence of these statements, and changes in the direction of demands. Second-order learning was measured in a similar way, i.e. studying the number of statements about underlying assumptions, and whether their content and direction was converging or diverging. Moreover, it was investigated whether mapping the

Box 1: Intermediary user organisations, the event themes studied (in italics) and the most important activities.

Dutch Neuromuscular Diseases Association (VSN; from 1968 to $2007 ; 2087$ incidents, 229 sources, 7 interviews)

gene therapy: following scientific developments, informing patients

stem cell therapy: following scientific developments, validating new therapies

exon-skipping: setting-up science networks, following scientific developments

enzyme replacement therapy: animal rights debates, clinical trials, reimbursement

idebenone: propagating clinical trials

experimental ALS drug: informing patients, propagating clinical trials

Steering Committee on Orphan drugs (WGM; from 1997 to 2006; 1022 incidents, 131 sources, 13 interviews)

orphan drug $R \& D$ : stimulating science networks and programmes

reimbursement of orphan drugs: policy debates about financing expensive drugs

Breast Cancer Association (BVN; from 1985 to 2007; 905 incidents, 578 sources, 8 interviews)

reimbursement of breast cancer drugs: policy debates about financing expensive drugs used in hospitals, such as the pharmacogenomics drug Herceptin. statements of first-order demands and second-order underlying assumptions on a timeline interconnected these two learning loops. Subsequently, it was investigated whether statements of one order are influenced by or even explicitly refers to previous statements of the other order. By this, it was determined whether statements of the two orders influenced each other.

7. Analysis demand articulation mechanisms: in four steps: (1) coding the first-order demand statements following the four steps of the first-order learning-loop, i.e. agenda-setting, synthesis, expression and evaluation; (2) recording the order of these steps; (3) investigating whether the order of steps was meaningful in relation to the content and (4) finding demarcating variations in the event categories that lead to the identification of different demand articulation mechanisms. The discerned loops were then scrutinised and characterised. Different circumstances or types of demand might result in different types of demand articulation mechanisms.

8. Triangulation of results: the narrative, analyses, and conclusions were presented to representatives of the intermediary, their interacting partners and more independent experts in order to obtain verification of the results found.

This methodology was applied in three Dutch intermediary user organisations all dealing with emerging technologies (see Box 1). These included the Breast Cancer Association BVN, the Dutch Neuromuscular Diseases Association VSN (both patient advocacy groups), and the Steering Committee on Orphan drugs WGM (a committee founded by the Dutch government to support the situation of patients with rare diseases).

The reasons for this focus on the Netherlands are the following: first, Dutch intermediary organisations in health care are well organised, transparent, and easy accessible. Second, demand articulation and interaction processes are actually taking place within these Dutch examples. Third, these organisations are illustrating examples of taking multiple stakeholders into account in technology decision-making processes.

\section{Results of demand articulation in intermediaries}

In this section we provide a narrative for every organisation of a demand articulation mechanism that was discerned. This serves as an illustration of all results about the internal learning processes inside intermediary user organisations, which are summarised in Tables 2 and 3. The results presented in these tables include whether first- and second-order learning occurred, whether these orders were interconnected, and whether we could discern demand articulation mechanisms in these learning loops.

\subsection{VSN: management of expectations about emerging technologies}

The VSN dealt with emerging technologies, such as gene therapy and stem cell therapy, as well as with reimbursement issues in the later stages of the drug innovation process. Regarding stem cell therapy, the VSN reiterated the promises of stem cell therapy, and the importance of R\&D in the field of neuromuscular diseases. However, the VSN was confronted by scientists and commercial parties, amongst others in the Netherlands and in China, which tried to sprint ahead of the 'stem cell bandwagon', sometimes violating scientific norms regarding safety and efficacy. In this context, the VSN articulated its demands following these steps:

- Scanning the scientific and clinical landscape and annotating new developments. 
Table 1

Operationalisation of event categories.

\begin{tabular}{|c|c|c|c|}
\hline Event categories & Dimensions & $\begin{array}{l}\text { Presence of } \\
\text { statements }\end{array}$ & Content of statements \\
\hline Agenda-setting & $\begin{array}{l}\text { - Decisions on agenda entrance of } \\
\text { problems, ideas, solutions, needs, etc. } \\
\text { - Weighing of entries } \\
\text { - Selecting (prioritising) them }\end{array}$ & $1 / 0$ & $\begin{array}{l}\text { Accept/reject } \\
\text { Important/unimportant } \\
\text { Pursue/not pursue }\end{array}$ \\
\hline Demand synthesis & $\begin{array}{l}\text { - Information gathering about } \\
\text { problems, ideas, solutions, needs, etc. } \\
\text { - Discussing and the forming of } \\
\text { problems, ideas, solutions, needs, etc. }\end{array}$ & $1 / 0$ & $\begin{array}{l}\text { Statements about information needed and plans to obtain it } \\
\text { Statements about the pros and cons of demands, argumentations, } \\
\text { timing of issuing, etc. }\end{array}$ \\
\hline Demand expression & $\begin{array}{l}\text { Expression of: } \\
\text { - Science fictions, visions, } \\
\text { 'Leitbilder'/'guiding visions', } \\
\text { expectations, promises } \\
\text { - Problems, obstacles } \\
\text { - Ideas, solutions, applications } \\
\text { - Needs } \\
\text { - Ethical, legal and social implications }\end{array}$ & $1 / 0$ & $\begin{array}{l}\text { Statements on the future ("we expect ...", "we anticipate ...", etc.) } \\
\text { Current situation is problematic } \\
\text { The actor acknowledges a problem, knows a direction for solutions, } \\
\text { and has some concrete ideas about how this end state should be } \\
\text { reached } \\
\text { The actor wants something } \\
\text { Statements on ethical, legal or social impacts }\end{array}$ \\
\hline Evaluation & $\begin{array}{l}\text { - Discussing validity of expression } \\
\text { - Discussing whether other actors } \\
\text { (re)acted on expressed demands }\end{array}$ & $1 / 0$ & $\begin{array}{l}\text { Statements on whether expressions still hold or should be amended } \\
\text { Statements on whether demands were heard by others and acted upon } \\
\text { (and whether action by the intermediary is needed again) }\end{array}$ \\
\hline Self-position & $\begin{array}{l}\text { - Ex-ante position by intermediary } \\
\text { - Ex-post position by intermediary } \\
\text { - Ultimate preferences }\end{array}$ & $1 / 0$ & $\begin{array}{l}\text { Reasoning behind operations, strategy, demands, problem-solving } \\
\text { ('how to get from the current to the perfect end situation') stated } \\
\text { before or after the event } \\
\text { Desired identity or attitude, desired social order or desired position in } \\
\text { the field, major goals of the organisation ('perfect end situation') }\end{array}$ \\
\hline Other-position & $\begin{array}{l}\text { Other actor's opinion about an } \\
\text { organisation's position and ultimate } \\
\text { preferences }\end{array}$ & $1 / 0$ & Objectives and ultimate goal attributed to intermediary by others \\
\hline
\end{tabular}

- Obtaining more information about developments through meetings with experts and asking those responsible for the developments themselves.

- Articulating the VSN's views about the developments towards its members and requesting action from other stakeholders (policymakers, companies).

This sequence of events was also identified in other event themes, such as those in which the VSN dealt with gene therapy and an experimental drug for amyotrophic lateral sclerosis. This pattern is an example of a first-order learning loop dealing with expectations of new technologies. We categorised this pattern as the demand articulation mechanism called 'management of expectations'.

During these first-order loops, the VSN also developed a sense of importance of managing expectations, which we regarded as second-order learning. The patient organisation identified three reasons to deal with the management of expectations: (1) new technologies induce enthusiasm, promises and expectations. As we encountered in the case studies, such as the study on stem cell therapy, expectations and promises can be 'performative' when they turn into requirements and in this way result in a self-fulfilling prophecy (Van Lente, 1993; Borup et al., 2006). Patients with no hope of recovery intensify this prophecy in their despair. Patient advocacy groups and other intermediary user organisations are aware of the risks of being ahead of the pack: their respectability is at stake and it might jeopardise scientific developments because too much resistance is created. They need to determine whether a technology is intrinsically novel and emergent or merely advertised as such as part of rhetoric efforts (Brown and Webster, 2004). On the other hand, constantly downplaying new developments might result in less (financial or scientific) attention. There needs to be a balance in spurring new science and technology and at the same time avoid being overenthusiastic and by this endanger the safety and efficacy of the new field; (2) patients can be educated about the way in which pharmaceutical R\&D works, which would make them employable as active 'lay-experts'. Nevertheless, the VSN always leaves the choice to the patients, and if patients, despite the warnings, want to adopt a new therapy, they encourage measurement of safety and efficacy data and (3) the VSN positions itself as a responsible actor in the field and hopes to be seen as such in order to increase the chances of being involved in the management and policy of pharmaceutical and health care innovations.

Scrutinising the sequence in which first- and second-order learning occurred, we established that in this intermediary organisation first- and second-order learning were connected. For example, this interaction was apparent in the experimental ALS drug event theme in which the second-order positioning created problems concerning the representation and 'expertification' of patients. In that case scientists published premature data about the efficacy of a compound for treating ALS through Dutch public media. One patient wanted the VSN to advocate for early release of this compound. Instead the VSN took up a different position by articulating the importance of finding confirmation of safety and efficacy through clinical trials as being more important for the ALS patient population as a whole.

From the results presented above and in Table 2, it can be concluded that first-order and second-order learning occurred quite often in the event themes studied. Moreover, these learning loops are intertwined. A variety of demand articulation mechanisms are characterised, such as the management of expectations, network 
Table 2

Summary of first-order and second-order learning over the cases.

\begin{tabular}{|c|c|c|c|c|c|c|c|c|c|}
\hline Event theme & $\begin{array}{l}\text { Demand } \\
\text { increase }\end{array}$ & $\begin{array}{l}\text { Convergence of } \\
\text { demand }\end{array}$ & $\begin{array}{l}\text { Direction } \\
\text { in demand }\end{array}$ & $\begin{array}{l}\text { Examples of } \\
\text { content of } \\
\text { first-order learning }\end{array}$ & $\begin{array}{l}\text { Second-order } \\
\text { learning? }\end{array}$ & $\begin{array}{l}\text { Examples of } \\
\text { second-order learning }\end{array}$ & $\begin{array}{l}\text { Second-order } \\
\text { learning loop? }\end{array}$ & $\begin{array}{l}\text { Interaction } \\
\text { first-order and } \\
\text { second-order } \\
\text { learning? }\end{array}$ & $\begin{array}{l}\text { Characteristics of this } \\
\text { interaction }\end{array}$ \\
\hline \multicolumn{10}{|l|}{ VSN } \\
\hline I. Gene therapy & Moderate & No & Yes & $\begin{array}{l}\text { Expectations about } \\
\text { the gene therapy } \\
\text { future }\end{array}$ & Yes & $\begin{array}{l}\text { How to deal with } \\
\text { emerging technology, } \\
\text { how to manage } \\
\text { expectations, and why? }\end{array}$ & No & Yes & $\begin{array}{l}\text { Legitimisation; } \\
\text { self-positioning is partly } \\
\text { influenced by first-order } \\
\text { learning; reactive weighing }\end{array}$ \\
\hline II. Exon-skipping & $\begin{array}{l}\text { First period } \\
\text { more than in } \\
\text { second }\end{array}$ & No & No & $\begin{array}{l}\text { Building science for } \\
\text { Duchenne; } \\
\text { expectations about } \\
\text { exon-skipping } \\
\text { future }\end{array}$ & Moderate & $\begin{array}{l}\text { Only in early stages when } \\
\text { setting-up activities }\end{array}$ & No & Yes & $\begin{array}{l}\text { Legitimisation of activities } \\
\text { and proactive weighing }\end{array}$ \\
\hline III. Stem cell therapy & Yes & Yes & No & $\begin{array}{l}\text { Expectations about } \\
\text { stem cell therapy; } \\
\text { dealing with } \\
\text { alternative } \\
\text { medicine }\end{array}$ & Moderate & $\begin{array}{l}\text { Only on how to manage } \\
\text { expectations }\end{array}$ & No & Yes & $\begin{array}{l}\text { Legitimisation; evaluation } \\
\text { through feedback from } \\
\text { others; pro/reactive } \\
\text { weighing }\end{array}$ \\
\hline IV. Pompe ERT & Yes & Yes & No & $\begin{array}{l}\text { Animal } \\
\text { biotechnology; } \\
\text { setting up clinical } \\
\text { trials; } \\
\text { reimbursement; } \\
\text { compassionate use }\end{array}$ & Yes & $\begin{array}{l}\text { Constant and also } \\
\text { articulated because it } \\
\text { wanted to 'copy' the } \\
\text { approach to other } \\
\text { disease areas }\end{array}$ & Yes & Yes & $\begin{array}{l}\text { Legitimisation; evaluation; } \\
\text { timing; } \\
\text { continue/discontinue } \\
\text { decisions (proactive } \\
\text { weighing) }\end{array}$ \\
\hline V. Idebenone & $\begin{array}{l}\text { First period } \\
\text { moderate; } \\
\text { second period } \\
\text { yes }\end{array}$ & $\begin{array}{l}\text { First period } \\
\text { moderate; } \\
\text { second period } \\
\text { yes }\end{array}$ & No & $\begin{array}{l}\text { Setting up and } \\
\text { organising clinical } \\
\text { trials }\end{array}$ & Yes & $\begin{array}{l}\text { Learning about dealing } \\
\text { with R\&D stimulation } \\
\text { and steering; clinical } \\
\text { trials; and policy } \\
\text { regarding } \\
\text { non-innovative drugs }\end{array}$ & No & Yes & $\begin{array}{l}\text { Legitimisation; evaluation; } \\
\text { reactive weighing }\end{array}$ \\
\hline VI. TCH346 & Yes & $\begin{array}{l}\text { Convergence } \\
\text { followed by } \\
\text { divergence and } \\
\text { convergence } \\
\text { again }\end{array}$ & No & $\begin{array}{l}\text { Setting up and } \\
\text { organising clinical } \\
\text { trials }\end{array}$ & Yes & $\begin{array}{l}\text { Learning how to deal } \\
\text { with R\&D stimulation } \\
\text { when genetic origin of } \\
\text { disease is unknown; } \\
\text { learning about balancing } \\
\text { representation of } \\
\text { patients }\end{array}$ & Yes & Yes & $\begin{array}{l}\text { Legitimisation; evaluation; } \\
\text { pro/reactive weighing }\end{array}$ \\
\hline \multicolumn{10}{|l|}{ WGM } \\
\hline Reimbursement & Yes & Yes & No & $\begin{array}{l}\text { How to organise } \\
\text { reimbursement, } \\
\text { e.g. through special } \\
\text { reimbursement } \\
\text { rule }\end{array}$ & Moderate & $\begin{array}{l}\text { Slow learning; no } \\
\text { changes in ultimate } \\
\text { preferences (solidarity); } \\
\text { maturing of organisation; } \\
\text { in first periods others } \\
\text { position WGM, later } \\
\text { more self-reflection }\end{array}$ & $\begin{array}{l}\text { Not in all } \\
\text { periods }\end{array}$ & Yes & $\begin{array}{l}\text { Legitimisation of demands; } \\
\text { evaluation of activities } \\
\text { (feedback); proactive } \\
\text { weighing }\end{array}$ \\
\hline Orphan drugs R\&D & Yes & No & No & $\begin{array}{l}\text { Inventories of rare } \\
\text { disease research; } \\
\text { ideas to set up } \\
\text { research } \\
\text { programme }\end{array}$ & Yes & $\begin{array}{l}\text { Profound because of need } \\
\text { for self-positioning (what } \\
\text { do they find important?) }\end{array}$ & Yes & Yes & $\begin{array}{l}\text { Underlying strategic } \\
\text { choices made; evaluation } \\
\text { (feedback); proactive } \\
\text { weighing }\end{array}$ \\
\hline \multicolumn{10}{|l|}{ BVN } \\
\hline Reimbursement Herceptin & Yes & Yes & No & $\begin{array}{l}\text { Concretise extent } \\
\text { of problem of } \\
\text { reimbursement; } \\
\text { calls for action }\end{array}$ & Yes & $\begin{array}{l}\text { No changes in ultimate } \\
\text { preferences (solidarity); } \\
\text { learning about how to } \\
\text { advocate }\end{array}$ & Yes & Yes & $\begin{array}{l}\text { Choices underlined; } \\
\text { evaluation (feedback); } \\
\text { legitimisation of demands; } \\
\text { reflection; proactive } \\
\text { weighing }\end{array}$ \\
\hline
\end{tabular}


Table 3

Demand articulation mechanisms found in the three cases.

\begin{tabular}{|c|c|c|}
\hline Type of demand articulation mechanism & Characteristics of demand articulation mechanism & Found in event theme on \\
\hline 'Management of expectations' (realism/enthusiasm) & $\begin{array}{l}\text { Reacting on scientific news or proactively scanning } \\
\text { scientific work leads to attempting to understand and } \\
\text { validate the information in cooperation with scientists. } \\
\text { Demands include disclaimers and balancing expectations } \\
\text { with realistic views }\end{array}$ & $\begin{array}{l}\text { Gene therapy, exon-skipping, stem cell } \\
\text { therapy, idebenone, TCH346 }\end{array}$ \\
\hline ‘Urging for action’ & $\begin{array}{l}\text { Scientific information is leading to proactively taking up a } \\
\text { topic and to asking others to take action, e.g. start clinical } \\
\text { trials. Intermediaries usually align with scientists in these } \\
\text { efforts }\end{array}$ & Stem cell therapy, TCH346 \\
\hline 'Stay on track' & $\begin{array}{l}\text { Proactively and continuously following developments, e.g. } \\
\text { on the development of a drug, through information } \\
\text { gathering and demand expression }\end{array}$ & Pompe ERT \\
\hline ‘Network building' & $\begin{array}{l}\text { Proactively setting up a network of actors with a } \\
\text { predefined goal and ideas. This is done by actively aligning } \\
\text { and preparing other actors }\end{array}$ & Exon-skipping, TCH346, WGM R\&D \\
\hline 'Following others' & $\begin{array}{l}\text { Reactively co-produce advocacy efforts initiated by others, } \\
\text { e.g. in interaction with the international patient group }\end{array}$ & Pompe ERT, TCH346, idebenone \\
\hline 'Active case building’ & $\begin{array}{l}\text { Proactively taking up an issue and building a case by } \\
\text { gathering information and aligning with external actors, } \\
\text { e.g. by producing facts and figures to support advocacy }\end{array}$ & $\begin{array}{l}\text { Pompe ERT, WGM reimbursement, } \\
\text { BVN }\end{array}$ \\
\hline ‘Administrative consultation' & $\begin{array}{l}\text { Information is produced as part of a formal consultation in } \\
\text { which the intermediary reactively participates. This } \\
\text { consultation is mostly initiated by a governmental agency }\end{array}$ & WGM reimbursement, BVN \\
\hline ‘Project stimulation’ & $\begin{array}{l}\text { Setting up small projects as experiments to stimulate } \\
\text { research on a more general level, e.g. for rare disease } \\
\text { research }\end{array}$ & WGM R\&D \\
\hline ‘Knee-jerk reaction’ & $\begin{array}{l}\text { Quick reactions to external events with virtually no } \\
\text { synthesis or preparation, although preliminary work } \\
\text { would certainly have been done in the context of other } \\
\text { cases or general positioning }\end{array}$ & $\begin{array}{l}\text { Pompe ERT, WGM reimbursement, } \\
\text { BVN }\end{array}$ \\
\hline 'Testing the waters' & $\begin{array}{l}\text { Ideas are expressed in rapid succession to learn what } \\
\text { others think about them. For example, how the WGM } \\
\text { should stimulate rare disease R\&D }\end{array}$ & WGM R\&D \\
\hline ‘Reflection’ & $\begin{array}{l}\text { Issues are proactively put on the agenda but subsequent } \\
\text { actions remain internal and are geared towards evaluation, } \\
\text { e.g. over longer period of time it is decided whether to } \\
\text { follow certain directions or topics }\end{array}$ & BVN \\
\hline ‘Unfinished business’ & $\begin{array}{l}\text { Issues are proactively put on the agenda but have not led } \\
\text { to a follow-up (so far) }\end{array}$ & Pompe ERT \\
\hline
\end{tabular}

building and following other actors. Especially the last one raises questions about the precarious balancing and positioning this intermediary user organisation was engaged in.

\subsection{WGM: aligning to formal consultation and proactive case-building}

The Steering Committee on Orphan drugs is concerned with drugs intended for diseases with a low prevalence. Because of these small patient populations, companies need to ask high prices for these orphan drugs. This led to problems around the reimbursement, especially in hospitals: in the old situation they needed to finance these drugs out of their own budgets. The WGM defined the problems and developed ideas about how to solve the reimbursement of orphan drugs. Ideas and problems seemed to propel each other as they spiralled into a progressive increase, whereas the focus of both problems and ideas were converging into one direction, i.e. establishing a special reimbursement policy rule for orphan drugs. All this indicates that first-order learning was occurring in this event theme.

Second-order learning pertained to developing the tasks and functions, and the way in which issues are placed on the agenda of an organisation. The level of reflexivity about these issues mirrors the stage of development ('maturity') of an intermediary organisation. Norms and preferences, mostly emphasising solidarity, remained unchanged. Nevertheless, they did influence the thinking about problems and ideas in such a way that every time choices about convergence were made, or problems and ideas were articulated, the WGM explicitly referred to their norms and values as a form of legitimisation. In this event theme, first- and second-order learning occurred and was interconnected.

At the start of this event theme the WGM took part in a formal consultation round organised by the government. This consultation round followed a formal order of events: reactive agenda-setting internally powered synthesis - expression in the form of a formal response - evaluation. This is called an 'administrative consultation' demand articulation mechanism. Later, the WGM took a more proactive stance and engaged in what we call an 'active case building' mechanism. This meant that it proactively put the problem on its internal agenda, requiring a thorough preparation and synthesis of demands. It started to construct a convincing case in which it both invested in producing full-blown consultations, reports, facts and figures, and in obtaining the support of other actors. During this process, the precise nature of the demands changed and converged. It resulted in a submission of a petition to parliament (expression) followed by an internal evaluation and many spin-off events. On the one hand, case building results into demands that are not easy to dismiss, but on the other hand it requires a lot of resources (knowledge, professionalism) that secure empowerment to produce these results.

All in all, a few demand articulation mechanisms were discerned, such as 'active case building' and 'administrative consultation' (see Table 2). In this case the importance of a proactive stance on policy issues regarding new science and technology was 
emphasised, in this way making a mark by articulating demands in an early stage of policymaking.

\subsection{BVN: proactive case-building and knee-jerk reactions}

The BVN primarily focused on issues at stake in the later stages of the innovation process, such as the reimbursement of expensive breast cancer drugs in hospitals. The problem has been a major topic in Dutch health care policy debates from, 1995 onwards. The breast cancer drugs Taxol and Herceptin are two major examples in this event theme. The reimbursement problem resembles the one described above in the context of orphan drugs. However, for Herceptin the problems intensified because medical specialists began to use the drug for an indication that had not been registered yet, and in this way could not be susceptible to central reimbursement. Hospitals were left with another pressure on their budgets.

The BVN, together with medical specialist groups, put pressure on the health ministry by sending letters. Later, the BVN invested heavily in the production of a report that showed inequalities in Herceptin prescription over different regions in the Netherlands. This event theme typically followed the same steps as described above in the 'active case building' mechanism. The Herceptin report had a massive impact and triggered reactions from different actors, some of which were quite forceful. The BVN responded to these by putting the issues on its internal agenda and by forming an immediate expression without much synthesis or deliberation. This can be discerned as a 'knee-jerk reaction' demand articulation mechanism. The impact of these quick actions is mostly large, depending on the intermediary's ability to react to the agenda setting in a quick way, and whether it concerns topics that attract media attention. The downside is that there is little time to prepare a proper demand statement or align with the organisation's underlying assumptions. In most instances this did not appear to be a problem because the organisation could have prepared itself in the context of other activities and had already developed their underlying assumptions in such a way that they were not faced with huge problems in expressing their demands quickly.

Regarding the demand articulation processes within the BVN we can conclude that first-order learning did occur in the context of the Herceptin event theme because the number of demands grew over time, and the level of concreteness also increased. Second-order learning also took place, e.g. on the way in which the BVN deals with patient advocacy. Moreover, first-order and second-order learning had a reciprocal influence on several occasions, e.g. by legitimising and evaluating demands.

Following the narratives above, Table 2 provides a full overview of first-order and second-order learning inside these three intermediary user organisations, as well as the interactions between firstand second-order learning.

Concerning the demand articulation inside intermediaries, several patterns were found in the first-order learning loops. From these patterns, demand articulation mechanisms were inductively and tentatively derived, some of which already have been presented above. A full list of mechanisms that were found in the event themes of the three case studies are summarised in Table 3.

The results show that first- and second-order learning occurred and that the two types of learning interacted (Table 2). At the same time, comparing the three intermediary user organisations shows that they might use distinct mechanisms to articulate their demands, depending on the issues involved or the situations they encounter. User organisations that deal more with the earlier stages of innovation processes use other mechanisms, such as 'management of expectations' in the development of stem cell therapy, than organisations that focus on the later stages, which use for example 'administrative consultation' and 'knee-jerk reactions'. These mechanisms differ in the degree of proactivity, but also have reper- cussions for the organisations themselves. In order to be effective in their demand articulation, it requires these organisations to be knowledgeable about the content of the science involved and about the rules and regulations of (debates about) innovation processes. In turn, this calls for more first-order learning and more reflection about aims and targets regarding second-order learning.

\section{Conclusions, discussion and recommendations}

The objective of this paper was to shed more light on processes of demand articulation by users in intermediary organisations. Hereto the analyses in the previous sections focused on demand articulation processes within three intermediary user organisations dealing with emerging technologies, such as pharmacogenomics, stem cell therapy, gene therapy, and enzyme replacement therapy. In the following we will discuss how the results of this empirical research contributed to answering the three research questions.

\subsection{Which learning mechanisms are discerned inside intermediary user organisations articulating their demands?}

The conclusions about the way in which demand articulation was taking shape, using demand articulation mechanisms, show that organised users are attempting to influence new technologies. In most cases, the hypothesised order of steps in the first-order learning loop, i.e. agenda - synthesis - expression - evaluation, was found. These loops can be characterised in different ways for distinct situations and organisations, and are labelled demand articulation mechanisms, such as 'management of expectations', 'network building', 'active case building' and 'knee-jerk reaction' (Table 3).

The identified demand articulation mechanisms illustrate how learning about demands in the context of emerging technologies is organised inside intermediary user organisations. For example, the demand articulation mechanisms 'managing expectations' and 'stay on track' involve a proactive investment in following science and new technologies, and subsequently synthesising and expressing a relevant need, idea or ethical concern. In other words, these intermediary organisations have incorporated demand articulation in their daily activities, in this way contributing to the governance of emerging technologies. Other reactions to new technologies are more reactive, indicated by the demand articulation mechanisms, such as 'knee-jerk reaction'. All in all, these demand articulation mechanisms provide insights into how intermediaries contribute to the governance of emerging technologies.

It merits the question to what extent users, and their representatives the intermediary user organisations, influenced the development of technologies. In the event themes studied here, ample evidence was found of intermediaries being involved in debates about new technologies, easing the boundary conditions for innovations and supporting scientific communities. Direct influence on the agenda setting of technology developers was less profound, although there were some examples visible. The emphasis of these organisations was more on the end stages of technology development. Furthermore, whether users were represented by the intermediaries and in that way had an influence on innovation is discussed below.

\subsection{Are the developed conceptual model and methodology useful to study processes of demand articulation in a particular sector, i.e. the health care sector in the Netherlands, and to what extent can this methodology also be used to analyse user involvement in the development of emerging technologies in a different context?}

To investigate how intermediaries deal with emerging technologies we introduced a model that conceptualises demand 
articulation as learning processes inside intermediary user organisations in the health care sector, focussing on first- and second-order learning processes (Fig. 1). It can be concluded that the premises underlying this model are to an extent supported by our empirical analysis. Table 2 shows that first-order and secondorder learning is taking place within these organisations and both learning processes are interconnected. These linkages can be typified as weighing of agenda items, legitimisation of actions and statements, and feedback during evaluation.

The event history analysis provides a suitable methodological approach to describe and analyse demand articulation because of its emphasis on the dynamic character of learning and demand articulation. The methodology proves useful to unravel and sharpen the dynamics of demand articulation in a structured and balanced way, taking into account interrater reliability and triangulation of data sources and types. There are also some points for improvement, e.g. to make the methodology less time-consuming, and to improve the transparency of second-order learning (the underlying assumptions). Lastly, this study focussed on representative user groups, whereas there are also other kinds of intermediary organisations. Research into the question to what extent our findings are applicable to different intermediary (user) organisations deserves more attention.

The question remains whether the conceptual model is also applicable to sectors, technologies and arenas outside the health care and pharmaceutical innovation system. In other words, under which conditions would the model be applicable in other fields? Apart from the fact that the content of the policy and management issues involved, and the related filling-in of the demand articulation mechanisms, is different for every case, we think that the model itself is rather robust. The concepts presented in the model, such as the first-order and second-order learning loops, are quite general and applicable to studying user involvement in innovation processes, more in particular demand articulation processes, in various sectors and technologies.

Also for more incumbent technologies the model could be useful, provided that a certain amount of development and reflection on demands and underlying assumptions is present in these technologies, in order to provide insights into learning dynamics. Further research should focus on the heterogeneity of (geographical, disease areas, etc.) contexts, in which intermediaries articulate their demands. Moreover, the analysis of demand articulation processes is based on retrospectively following intermediary organisations while they are engaged in the development of new technologies. What would also be interesting is whether these mechanisms play a role when demand articulation is studied prospectively.

\subsection{Which are the implications of the results for policy and for intermediary organisations?}

Intermediary organisations can be regarded as loci for demand articulation and co-producing (visions on) new technologies. Currently, governments struggle with the sustainability of their healthcare systems, concerning for example providing access to (new) medicines. At the same time, governments also seek to organise their innovation systems in such a way that they support innovations in healthcare and can drive economic growth. While pursuing these aims they engage with several actors who might have conflicting values and interests. As we have shown, intermediary user organisations can prove to be beneficial, either in an instrumental way by facilitating innovation processes, transferring and adding value to knowledge, or by contributing to broaden and enrich debates about new technologies. In Constructive Technology Assessment (CTA) processes intermediaries could be invited to independently counterbalance actors who tend to dominate the innovation arena by articulating an alternative voice (Rip et al., 1995; Smits et al., 2010). By this, these demands are proactively articulated as part of future-oriented governance of emerging technologies. Technology developers are then not taken by surprise by user needs or resistance later on, and can take these needs into account in the earlier stages of technology development when technologies are still malleable. At the same time, actors become aware of each others' demands and underlying values, which might lead to convergence of demands, unexpected alliances, and better understanding and legitimisation of diverging demands.

In order to make the contribution to CTA processes as effective as possible, the analyses of the three case studies showed that intermediary user organisations should take three challenges into account when striving after effective functioning as a locus for coproducing new technologies, from the perspective to enhance the democratic content of decision making on technology:

- Positioning: the position of intermediary organisations is contested because they are in interaction with a heterogeneous set of actors, and their objectives and functions are not as welldefined as those of other actors in the innovation system. This became apparent in the 'management of expectations' mechanism in the VSN case but was also implicit in the WGM and BVN narratives. Intermediaries need to be able to maintain a relationship with different actors. In order to be regarded as a serious, credible interaction partner, they need to balance the interests of their organisation (and their members) with taking an impartial or professional stance in interactions (Kolodny et al., 2001; Klerkx and Leeuwis, 2008). It should be noted that this premise depends heavily on the position the intermediary wants to take: some intermediaries take up a neutral, impartial, coordinating role, whereas others are more activists. The latter are (willing to be) confronted with more resistance, which can be beneficial since it potentially broadens the debate about technological options.

- Representation: as we have seen in Section 2.1, for intermediaries it is essential to speak on behalf of their members, the users, and picture their demands in a representative way. In this way they take into account the heterogeneity of demands that are relevant to the users. This enhances the democratic value of the organisations' internal decision-making and the debates in which these organisations participate. A lot of demand articulation mechanisms are about synthesising demands from users without interacting with them. Examples include 'administrative consultation' and 'knee-jerk reactions'. Organisations should refrain from simple representation of users without interacting with the represented actors.

- Level of proactivity: intermediary user organisations should respond to a great amount of pressures. As was discussed above, one of these challenges is dealing with the range of heterogeneous actors. Linked to this is their ability to be congruent with different situations and contexts. A related challenge is anticipating on new technologies. It is recommended to start as early as possible with proactively clarifying demands and underlying assumptions of the intermediary and those of other parties. In this way, intermediaries can better anticipate the course of the debate. Moreover, by creating a vision of future technologies in an early phase empowers the intermediary. Then, the intermediary organisation could claim the status of being a co-production locus of new technologies, and in this way is better equipped to steer the search for a shared vision on or demands for new technologies. Some demand articulation mechanisms that were identified are more proactive than others. For example, the 'active case building' and 'management of expectations' mechanisms show similarities with strategic intelligence methods, such as (constructive) technology assessment. However, these exercises 
require a certain degree of resources, long-term commitment, professionalism, and (context-) sensitivity.

The challenges show that intermediary user organisations play a precarious role in demand articulation in the context of new technologies. However, if these challenges can be overcome, the intermediary user organisations could and will play a central and crucial role in governing the co-production of new technologies. The conclusions we have drawn on intermediaries as co-producing loci are of importance for governance of upcoming new technologies. Broadening the governing process to heterogeneous actor groups with various coordinated roles and strategies can be beneficial for businesses, governments and users, and relates to recent development in demand-oriented innovation policy and management.

\section{References}

Argyris, C., Schön, D.A., 1978. Organizational Learning: A Theory of Action Perspective. Addison-Wesley Publishing Company, Reading, MA.

Bal, R., Bijker, W.E., et al., 2004. Democratisation of scientific advice. British Medical Journal 329, 1339-1341.

Bessant, J., Rush, H., 1995. Building bridges for innovation: the role of consultants in technology transfer. Research Policy 24 (1), 97-114.

Bijker, W.E., Hughes, T., et al., 1987. The Social Construction of Technological Systems. New Directions in the Sociology and History of Technology. MIT Press, Cambridge, MA.

Boon, W.P.C., 2008. Demanding dynamics - demand articulation of intermediary organisations in emerging pharmaceutical innovations (PhD thesis). Utrech University, Utrecht.

Boon, W.P.C., Moors, E.H.M., et al., 2008. Demand articulation in intermediary organisations: the case of orphan drugs in the Netherlands. Technological Forecasting and Social Change 75 (5), 644-671.

Borup, M., Brown, N., et al., 2006. The sociology of expectations in science and technology. Technology Analysis \& Strategic Management 18 (3/4), 285-298

Braun, D., 1993. Who governs intermediary agencies? Principal-agent relations in research policy-making. Journal of Public Policy 13 (2), 135-162.

Braun, D., Guston, D.H., 2003. Principal-agent theory and research policy: an introduction. Science and Public Policy 30 (5), 302-308.

Brown, N., Webster, A., 2004. New Medical Technologies and Society. Polity Press, Cambridge.

Burt, R.S., 1992. Structural Holes: The Social Structure of Competition. Harvard University Press, Cambridge.

Callon, M., 1986. Some elements of a sociology of translation: domestication of the scallops and the fishermen of St. Brieuc Bay. In: Law, J. (Ed.), Power, Action and Belief: A New Sociology of Knowledge. Routledge \& Kegan Paul, London.

Cohen, M.D., Sproull, L.S., 1995. Organizational Learning. Sage Publications, Thousand Oaks.

Davenport, S., Leitch, S., et al., 2003. The 'user' in research funding negotiation processes. Science and Public Policy 30 (4), 239-250.

Den Hertog, P., 2000. Knowledge-intensive business services as co-producers of innovation. International Journal of Innovation Management 4 (4), 491-528.

Edler, J., 2010. Demand-based innovation policy. In: Smits, R., Kuhlmann, S., Shapira, P. (Eds.), The Theory and Practice of Innovation Policy. Edward Elgar, Cheltenham.

Edler, J., Georghiou, L., 2007. Public procurement and innovation-resurrecting the demand side. Research Policy 36 (7), 949-963.

Edquist, C., 1997. Systems of Innovations. Technologies, Institutions and Organization. Pinter, London.

Epstein, S., 1995. The construction of lay expertise: AIDS activism and the forging of credibility in the reform of clinical trials. Science, Technology \& Human Values 20 (4), 408-437.

Epstein, S., 2008. Patient groups and health movements. In: Hackett, E.J., Amsterdamska, O., Lynch, M., Wajcman, J. (Eds.), Handbook of Science and Technology Studies, third ed. MIT Press, Cambridge, MA, pp. 499-537.

Fernandez, R.M., Gould, R.V., 1994. A dilemma of state power: brokerage and influence in the national health policy domain. American Journal of Sociology 99 (6) $1455-1491$.

Fischer, F., 2000. Citizens, Experts, and the Environment. Duke University Press, Durham, NC.

Galli, R., Teubal, M., 1997. Paradigmatic shifts in national innovation systems. In: Edquist, C. (Ed.), Systems of Innovation. Pinter, London/Washington.

Grin, J., Van de Graaf, H., 1996a. Technology assessment as learning. Science, Technology \& Human Values 21 (1), 72-99.

Grin, J., Van de Graaf, H., 1996b. Implementation as communicative action - an interpretative understanding of interactions between policy actors and target groups. Policy Sciences 29, 291-319.

Hennen, L., 1999. Participatory technology assessment: a response to technical modernity? Science and Public Policy 26 (5), 303-312.

Hess, D., Breyman, S., et al., 2008. Science, technology, and social movements. In: Hackett, E.J., Amsterdamska, O., Lynch, M., Wajcman, J. (Eds.), Handbook of Science and Technology Studies, third ed. MIT Press, Cambridge, MA, pp. 473-498.
Hess, D.J., 2004. Medical modernisation, scientific research fields and epistemic politics of health social movements. Sociology of Health \& Illness 26 (6), 695-709.

Hess, D.J., 2005. Technology- and product-oriented movements: approximating social movement studies and science and technology studies. Science, Technology \& Human Values 30 (4), 515-535.

Howells, J., 2006. Intermediation and the role of intermediaries in innovation. Research Policy 35, 715-728.

Kaufmann, A., Tödtling, F., 2001. Science-industry interaction in the process of innovation: the importance of boundary-crossing between systems. Research Policy $30,791-804$.

Khurana, R., 2002. Market triads: a theoretical and empirical analysis of market intermediation. Journal of the Theory of Social Behaviour 32 (2), 239262.

Klerkx, L., Leeuwis, C., 2008. Institutionalizing end-user demand steering in agricultural R\&D: farmer levy funding of R\&D in The Netherlands. Research Policy 37 (3), 460-472.

Klerkx, L., Leeuwis, C., 2009. Establishment and embedding of innovation brokers at different innovation system levels: insights from the Dutch agricultural sector. Technological Forecasting and Social Change 76 (6), 849-860.

Kodoma, F., 1995. Emerging Patterns on Innovation: Sources of Japan's Technological Edge. Harvard Business School Press, Boston.

Kolodny, H., Stymne, B., et al., 2001. Design and policy choices for technology extension organizations. Research Policy 30 (2), 201-225.

Latour, B., 1987. Science in Action: How to Follow Scientists and Engineers Through Society. Harvard University Press, Cambridge, MA.

Lundvall, B.A., 1992. National Systems of Innovation: Towards a Theory of Innovation and Interactive Learning. Pinter Publishers, London.

Meeus, M.T.H., Oerlemans, L.A.G., et al., 2001. Patterns of interactive learning in a high-tech region. Organization Studies 22 (1), 145-172.

Merkx, F., 2008. Organizing responsibilities for novelties in medical genetics. In: Dynamics and Productivity of Mutual Positioning in Hybrid Forums. University of Twente, Enschede.

Mohr, L., 1982. Explaining Organizational Behavior. Jossey-Bass, San Francisco.

Moors, E.H.M., Boon, W.P.C., et al., 2008. User-producer interactions in emerging pharmaceutical and food innovations. International Journal of Innovation Management 12 (3), 459-487.

Orihata, M., Watanabe, C., 2000. The interaction between product concept and institutional inducement: a new driver of product innovation. Technovation 20, 11-23.

Oudshoorn, N., Pinch, T., 2003. How Users Matter - The Co-construction of Users and Technology. The MIT Press, Cambridge, MA.

Parthasarathy, S., 2003. Knowledge is power: genetic testing for breast cancer and patient activism in the United States and Britain. In: Oudshoorn, N., Pinch, T. (Eds.), How Users Matter - The Co-construction of Users and Technology. The MIT Press, Cambridge, MA

Poole, M.S., 2004. Central issues in the study of change and innovation. In: Poole, M.S., Van de Ven, A.H. (Eds.), Handbook of Organizational Change and Innovation. Oxford University Press, Oxford, pp. 3-31.

Rabeharisoa, V., 2003. The struggle against neuromuscular diseases in France and the emergence of the partnership model of patient organisation. Social Science and Medicine 57, 2127-2136.

Rip, A., 1995. Introduction of new technology: making use of recent insights from sociology and economics of technology. Technology Analysis \& Strategic Management 7 (4), 417-431.

Rip, A., Misa, T.J., et al., 1995. Managing Technology in Society: The Approach of Constructive Technology Assessment. Pinter Publishers, London.

Robinson, D.K.R., Rip, A., et al., 2007. Technological agglomeration and the emergence of clusters and networks in nanotechnology. Research Policy 36 (6) 871-879.

Rothwell, R., Freeman, C., et al., 1974. SAPPHO updated - project SAPPHO phase II. Research Policy 3 (3), 258-291.

Schot, J., Rip, A., 1996. The past and future of constructive technology assessment Technological Forecasting and Social Change 54 (4), 251-268.

Smits, R., Leyten, A., et al., 1995. Technology assessment and technology policy in Europe: new concepts, new goals, new infrastructures. Policy Sciences 28 , 272-299.

Smits, R.E.H.M., Boon, W.P.C., 2008. The role of users in innovation in the pharmaceutical industry. Drug Discovery Today 13 (7/8), 353-359.

Smits, R., van Merkerk, R., et al., 2010. Strategic intelligence: the role of TA in systemic innovation policy. In: Smits, R., Kuhlmann, S., Shapira, Q. (Eds.), The Theory and Practice of Innovation Policy. Edward Elgar, Cheltenham.

Van de Ven, A.H., Engleman, R.M., 2004. Event- and outcome-driven explanations of entrepreneurship. Journal of Business Venturing 19, 343-358.

Van de Ven, A.H., Polley, D.E., et al., 1999. The Innovation Journey. Oxford University Press, Oxford

Van de Ven, A.H., Poole, M.S., 1990. Methods for studying innovation development in the Minnesota Innovation Research Program. Organization Science 1 (3), 313-335.

Van der Meulen, B., Nedeva, M., et al., 2005. Intermediaries organisation and processes: theory and research issues. In: PRIME Workshop, The Netherlands.

Van der Meulen, B., Rip, A., 1998. Mediation in the Dutch science system. Research Policy 27, 757-769.

Van Lente, H., 1993. Promising technology: the dynamics of expectations in technological developments. In: Faculteit der Wijsbegeerte en Maatschappijwetenschappen. Universiteit Twente, Enschede. 
Van Lente, H., Hekkert, M., et al., 2003. Roles of systemic intermediaries in transition processes. International Journal of Innovation Management 7 (3), 1-33.

Von Hippel, E., 1978. A customer-active paradigm for industrial product idea generation. Research Policy 7, 240-266.

Von Hippel, E., 1988. The Sources of Innovation. Oxford University Press, Oxford.

Wouter Boon is a postdoc researcher at the Department of Innovation Studies, Utrecht University, The Netherlands. His research focuses on demand articulation in intermediary organisations and user involvement in the field of emerging innovations.
Ellen Moors is an associate professor at the Department of Innovation Studies, Utrecht University, The Netherlands. She is working on user-producer interactions and life sciences innovations.

Stefan Kuhlmann is a professor for 'Foundations of Science, Technology and Society' at the Department of Science, Technology, and Policy Studies, University of Twente, The Netherlands.

Ruud Smits is a professor for 'Governance and Innovation Systems' at the Department of Innovation Studies, Utrecht University, The Netherlands. 